\title{
Upaya Peningkatan Pengetahuan Siswa SMK/SMA Mengenai Kosmetik yang Aman dengan Metode Daring
}

\section{Djamilah Arifiyana ${ }^{1}$}

${ }^{1}$ Akademi Farmasi Surabaya, Surabaya

E-mail: djamilah.chemits@gmail.com

\author{
Vika Ayu Devianti² \\ ${ }^{2}$ Akademi Farmasi Surabaya, Surabaya \\ E-mail:vikaayu@akfarsurabaya.ac.id
}

\begin{abstract}
Article History:
Received: 2021-09-03

Revised: 2021-12-26

Accepted:2022-01-25

Keywords : Education, Knowledge, Cosmetic

Abstract: The rise of media coverage regarding the production of illegal and dangerous cosmetics is one proof that the use of cosmetics is currently a necessity. Online marketing is one of the facilities for spreading these illegal cosmetics. Thus, it is necessary to educate the public, especially social media users who are generally in productive age range, to be more careful in choosing safe cosmetics. In this activity, education was carried out to 17 participants from senior high school student. Senior high school student were chosen because they represent the productive age community who still need direction in making decisions. The method used includes the presentation by the presenter as well as discussion and question and answer. To measure the increase in knowledge, pre-test and posttest were carried out. It was found that 64.7\% experienced an increase in knowledge after this activity was held.
\end{abstract}




\section{Riwayat Artikel:}

Diajukan: 03-09-2021

Diperbaiki: 26-12-2021

Diterima: 25-01-2022
Kata kunci : Edukasi, Pengetahuan, Kosmetik

\begin{abstract}
Abstrak: Maraknya pemberitaan media mengenai produksi kosmetik ilegal dan berbahaya adalah fakta bahwa penggunaan kosmetik saat ini menjadi salah satu kebutuhan. Pemasaran secara daring merupakan salah satu fasilitas pernyebaran kosmetik ilegal tersebut. Dengan demikian perlu adanya edukasi terhadap masyarakat, khususnya pengguna media sosial yang rata-rata berada pada usia produktif untuk lebih waspada ketika memilih kosmetik. Pada kegiatan pengabdian kepada masyarakat ini edukasi dilakukan terhadap siswa(i) SMA dan SMK yang berjumlah 17 peserta. Siswa(i) SMA dan SMK dipilih karena merupakan representasi dari masyarakat usia produktif yang masih membutuhkan arahan dalam mengambil keputusan. Metode yang dilakukan meliputi pemaparan oleh pemateri serta diskusi dan tanya jawab. Untuk mengukur peningkatan penetahuan, dilakukan pre-test dan posttest. Diperoleh hasil sebanyak $64,7 \%$ mengalami peningkatan pengetahuan setelah diadakannya kegiatan ini.
\end{abstract}

\section{Pendahuluan}

Saat ini media sosial menjadi platform yang sangat populer untuk mempromosikan produk-produk kosmetik. Promosi produk kosmetik yang melalui orang-orang berpengaruh seperti selebgram menjamur dimana-mana. Disisi lain banyak sekali pemberitaan maraknya kosmetik palsu atau abal-abal. Pada tahun 2018, BPOM RI bersama Bareskrim Mabes Polri berhasil menggerebek rumah yang memproduksi kosmetik ilegal dan kosmetik palsu di Jakarta Barat. 21 jenis (39.389 pieces) produk kosmetik disita, dimana kosmetik-kosmetik tersebut diduga kuat mengandung merkuri atau hidrokinon (Maulana, 2018). Hidrokuinon 
sendiri merupakan senyawa yang sangat berbahaya dan berpotensi bersifat karsinogenik (Arifiyana, Harijanti dan Ebtavanny, 2019). Sepanjang tahun 2021, banyak pemberitaan terkait pembuatan dan peredaran kosmetik ilegal.

Awal tahun 2021, kita dikejutkan kembali dengan berita Polda Metro Jaya yang melakukan penggerebekan pabrik kosmetik ilegal di Jatiasih, Jawa Barat, dimana ternyata pabrik yang memproduksi kosmetik tersebut dipasarkan secara daring dan beroperasi sejak tahun 2018 (Rassat, 2021). Masih dibulan yang sama, polisi menggerebek 3 rumah warga kota Makasar dan ditemukan sebanyak 850 paket kosmetik ilegal (Mappiwali, 2021). Pada bulan Februari 2021, Direktorat Reserse Narkoba (Ditnarkoba) Polda Jawa Barat menggerebek sebuah rumah di Padalarang, Kabupaten Bandung Barat yang digunakan sebagai pabrik kosmetik ilegal. Proses produksi kosmetik ini dilakukan secara manual dan menggunakan beberapa pewarna makanan. Kegiatan ini telah berlangsung selama 2 tahun (Kautsar, 2021). Juni 2021, Unit Reserse Kriminal (Reskrim) Polsek Tanjung Karang Timur menggerebek gudang yang diduga jadi tempat penyimpanan kosmetik ilegal. Menurut pengakuan tersangka total sudah ada sekitar 50 ribu botol yang berhasil diproduksi dan yang beredar ada sekitar 11 ribu botol kosmetik yang berfungsi sebagai pemutih wajah (Geh, 2021). Pada 23 September 2021, kepolisian Polda Sumatera Selatan meringkus sepasang suami istri penjual kosmetik ilegal. Polisi menyita ribuan kosmetik ilegal tanpa izin edar BPOM (Wirachmi, 2021).

Pada dasarnya, kosmetik yang aman harus memenuhi beberapa persyaratan, selain bebas dari kandungan berbahaya seperti hidrokuinon, kosmetik juga memiliki batasan dari segi kandungan logam berat. Berdasarkan Peraturan Kepala Badan Pengawas Obat dan Makanan Republik Indonesia Nomor 17 Tahun 2014 tentang Perubahan Atas Peraturan Kepala Badan Pengawas Obat dan Makanan Nomor HK.03.1.23.07.11.6662 Tahun 2011 Tentang Persyaratan Cemaran Mikroba dan Logam Berat dalam kosmetika, terdapat empat jenis logam berat yang dibatasi kandungannya, yaitu timbal (Pb), kadmium ( $\mathrm{Cd}$ ), arsenik (As) dan merkuri $(\mathrm{Hg})$. Selain itu, untuk melindungi konsumen, BPOM telah memfasilitasi masyarakat untuk secara mandiri dapat memastikan legalitas dari produk obat, makanan dan kosmetik melalui web (https://cekbpom.pom.go.id/). Namun, pengetahuan masyarakat, khususnya pengguna media sosial, yang umumnya berada pada usia produktif masih dinilai 
kurang. Sehingga perlu adanya kegiatan edukasi untuk menyebarluaskan pengetahuan mengenai kriteria kosmetika yang aman dan cara memastikan kosmetika yang akan dikonsumsi telah teregistrasi BPOM. Apalagi konsumsi kosmetik belakangan ini telah menjadi salah satu kebutuhan sehari-hari dan konsumennya pun tidak hanya terbatas pada kalangan wanita saja, tetapi pria juga (Arifiyana dan Fernanda, 2018).

Pada usia remaja dimana persepsi diri tidak selalu objektif, terlepas dari penampilan dan kemampuan yang yang sesungguhnya, terdapat pandangan jelek, rendah dan kurang. Hal tersebut merupakan cerminan ketidakpuasan terhadap diri mereka sendiri (Mappiare, 1982). Penelitian yang dilakukan oleh Pratiwi (2011) menyimpulkan bahwa terdapat hubungan negatif antara konsep diri pada remaja putri terhadap kebiasaan membeli kosmetik yang berfungsi sebagai pemutih wajah. Ini artinya bahwa remaja yang memiliki konsep diri rendah, maka akan cenderung membeli kosmetik pemutih wajah, begitu pula sebaliknya. Kateksistubuh atau perasaan puas terhadap tubuh hanya dialami oleh sejumlah kecil remaja, dimana ketidakpuasan tersebut lebih banyak dirasakan pada beberapa bagian tubuh tertentu, misalnya pada bagian wajah. Hal tersebut dialami oleh remaja yang menginjak masa SMA/SMK. Disisi lain, saat ini promosi penggunaan produk kosmetik atau perawatan wajah (skincare) sangat massif disegala jenis platform. Target konsumennya pun beragam, termasuk remaja usia SMA/SMK yang masih mencari jatidiri. Pada dasarnya, usia produktif tidak hanya merujuk pada remaja usia SMA/SMK, remaja pada usia yang menempuh pendidikan di perguruan tinggi hingga karyawan kantoran juga tergolong usia produktif. Namun, usia produktif pada golongan masyarakat ini dinilai telah terpapar pengetahuan lebih banyak, misalnya melalui jurnal ilmiah atau pemberitaan di media massa/online, sehingga dianggap telah mengetahui resiko dan bahaya kosmetik berbahaya dan mampu memilih produk kosmetik sesuai kebutuhan secara bijak. Oleh karena itu, masyarakat sasaran yang dipilih merupakan siswa SMA/SMK yang dinilai masih membutuhkan edukasi dalam memilih jenis produk kosmetik yang aman. 


\section{Metode}

\section{Pelaksanaan Kegiatan}

Kegiatan Pengabdian kepada Masyarakat berupa edukasi tentang pemilihan kosmetik yang aman dilaksanakan secara daring melalui Google Meet kepada siswa SMK/SMA pada hari Minggu, 29 Maret 2021. Narasumber yang menyampaikan materi merupakan dosen dan mahasiswa Akademi Farmasi Surabaya yang meneliti tentang logam berat, termasuk logam berat dalam sediaan kosmetik. Kriteria masyarakat sasaran pada kegiatan ini yaitu siswa SMA/SMK yang sedang dalam masa studi. Metode yang digunakan dalam menarik minat masyarakat sasaran yaitu melalui publikasi di media sosial, serta ajakan secara langsung oleh panitia mahasiswa sebagai alumni. Adapun detail kegiatan adalah sebagai berikut.

Tabel 1. Susunan Kegiatan

\begin{tabular}{|c|c|c|}
\hline Jadwal Kegiatan & Durasi & Kegiatan \\
\hline Persiapan Kegiatan & 10 menit & Panitia \& Peserta masuk room Google Meet \\
\hline Pembukaan & 5 menit & $\begin{array}{l}\text { - } \text { MC membuka acara } \\
\text { - } M C \text { membacakan peraturan seputar } \\
\text { kegiatan } \\
\text { - Sambutan Ketua Panitia Acara }\end{array}$ \\
\hline Pre-test & 10 menit & $\begin{array}{l}\text { Peserta mengisi kuesioner melalui Google Form } \\
\text { yang disediakan panitia (pre-test) }\end{array}$ \\
\hline Pemaparan Materi & 45 menit & $\begin{array}{l}\text { - Kosmetika dan Bahan Berbahaya pada } \\
\text { Kosmetik } \\
\text { - } \text { Tips Memilih Kosmetik yang Aman } \\
\text { - Logam Berat dalam Kosmetik } \\
\text { - Simulasi Simulasi cara menggunakan cek } \\
\text { produk secara online melalui website Badan } \\
\text { POM (https://cekbpom.pom.go.id/) }\end{array}$ \\
\hline Sesi Tanya Jawab & 15 menit & $\begin{array}{l}\text { Peserta mengajukan pertanyaan kepada tim } \\
\text { pemateri dipandu oleh MC }\end{array}$ \\
\hline Post-test & 10 menit & $\begin{array}{l}\text { Peserta mengisi kuesioner kembali melalui } \\
\text { Google Form yang disediakan panitia (post-test) }\end{array}$ \\
\hline Penutup & 10 menit & $\begin{array}{l}\text { MC menutup acara, membagikan Doorprize dan } \\
\text { sesi foto bersama }\end{array}$ \\
\hline
\end{tabular}




\section{Evaluasi Peningkatan Pengetahuan}

Evaluasi dilakukan untuk mengukur tingkat keberhasilan dari kegiatan ini. Parameter keberhasilan kegiatan ini dilihat dari meningkatnya pengetahuan masyarakat sasaran, dalam hal ini siswa SMA/SMA, mengenai pemilihan kosmetik yang aman. Evaluasi dinilai melalui animo peserta pada sesi tanya jawab. Selain itu, evaluasi terhadap peningkatan pengetahuan pada kegiatan ini dilakukan melalui pengisian kuesioner diawal (pre-test) dan diakhir (posttest) kegiatan. Kuesioner yang diberikan berisi pertanyaan-pertanyaan berbentuk pilihan ganda (multiple choice) tentang materi yang disampaikan saat kegiatan berlangsung. Jika nilai post-test peserta yang diperoleh lebih tinggi daripada pre-test, maka hal tersebut mengindikasikan bahwa penyuluhan ini telah berhasil meningkatkan pengetahuan. Berikut adalah daftar pertanyaan dalam kuesioner.

Tabel 2. Daftar Pertanyaan dalam Kuesioner

No. Pertanyaan

1. Lembaga yang mengawasi segala hal tentang kosmetika adalah...
A. BUMN
B. BPOM
C. FDO

2. Kosmetik berasal dari kata Yunani "Kosmetikos" yang berarti...

A. Keterampilan berpakaian dan menghias

B. Keterampilan menghias atau mengatur

C. Keterampilan merawat kulit wajah dan rambut

3. Definisi kosmetik menurut Kepala BPOM RI tercantum pada peraturan nomor ..
A. Nomor 23 tahun 2019
B. Nomor 23 tahun 2018
C. Nomor 22 tahun 2019

4. Apakah shampoo tergolong dalam produk kosmetika?
A. Benar
B. Salah
C. Ragu-ragu

5. Apakah bahaya dari salah memilih produk kosmetik?
A. Varises
B. Iritasi kulit
C. Timbul cacar air

6. Apakah yang tidak perlu diperhatikan sebelum membeli kosmetik?
A. Izin edar
B. Kadaluarsa kosmetik 
C. Warna dan bau kosmetik

7. Sepengetahuan anda, apakah boleh digunakan kosmetik untuk pemakaian bersama?
A. Boleh
B. Tidak boleh
C. Tidak tahu

8. Dimanakan tempat untuk melakukan uji kepekaan kosmetik? Kecuali...
A. Di wajah
B. Di area belakang telinga
C. Di bagian dalam siku

9. Bagaimana ciri-ciri kosmetik impor ilegal? Kecuali...
A. Tidak terdapat nomor izin edar BPOM
B. Dijual secara online
C. Informasi label berbahasa asing dan Indonesia

10. Apakah website resmi dari BPOM guna untuk mengecek izin edar?
A. cekbpom.pom.go.id
B. cekizinedar.bpom.go.id
C. izinedar.pom.com

11. Manakah sumber kontaminasi logam berat pada kosmetik?
A. Perairan sekitar tempat industri
B. Alat industri yang digunakan selama proses produksi
C. Bahan alam mineral

12. Logam manakah yang kadarnya dalam kosmetik diatur oleh pemerintah Indonesia?
A. Arsenik dan Timbal
B. Kadmium dan Besi
C. Nikel dan Merkuri

13. Manakah dari jalur berikut ini yang BUKAN merupakan kemungkinan paparan logam berat dalam kosmetik?
A. Oral
B. Kulit
C. Saraf

14. Berapa banyak jenis logam berat yang dibatasi jumlah cemarannya dalam kosmetika oleh BPOM?
A. 4
B. 7
C. 10

15. Berikut ini manakah cara yang dapat dilakukan untuk mengetahui adanya cemaran logam berat dalam kosmetik?
A. Diaplikasikan langsung pada tubuh
B. Melalui pengujian di laboratorium
C. Digosok dengan cincin emas 


\section{Hasil dan Diskusi}

\section{Pelaksanaan Kegiatan}

Kegiatan Pengabdian kepada Masyarakat dilakukan secara daring melalui Google Meet. Jumlah siswa yang mengikuti kegiatan ini berdasarkan data presensi yang juga berisi identitas diri sebanyak 27 siswa. Jumlah pengisi pre-test telah sesuai dengan jumlah presensi awal kegiatan, namun pada pengisian post-test jumlah responden yang mengisi sebanyak 17 siswa, atau sebanyak 63\% kuesioner terisi penuh sebelum dan sesudah kegiatan (daftar pertanyaan dalam kuesioner disajikan pada Tabel 2). Dengan demikian, data yang disajikan adalah data pada 17 peserta kegiatan saja.

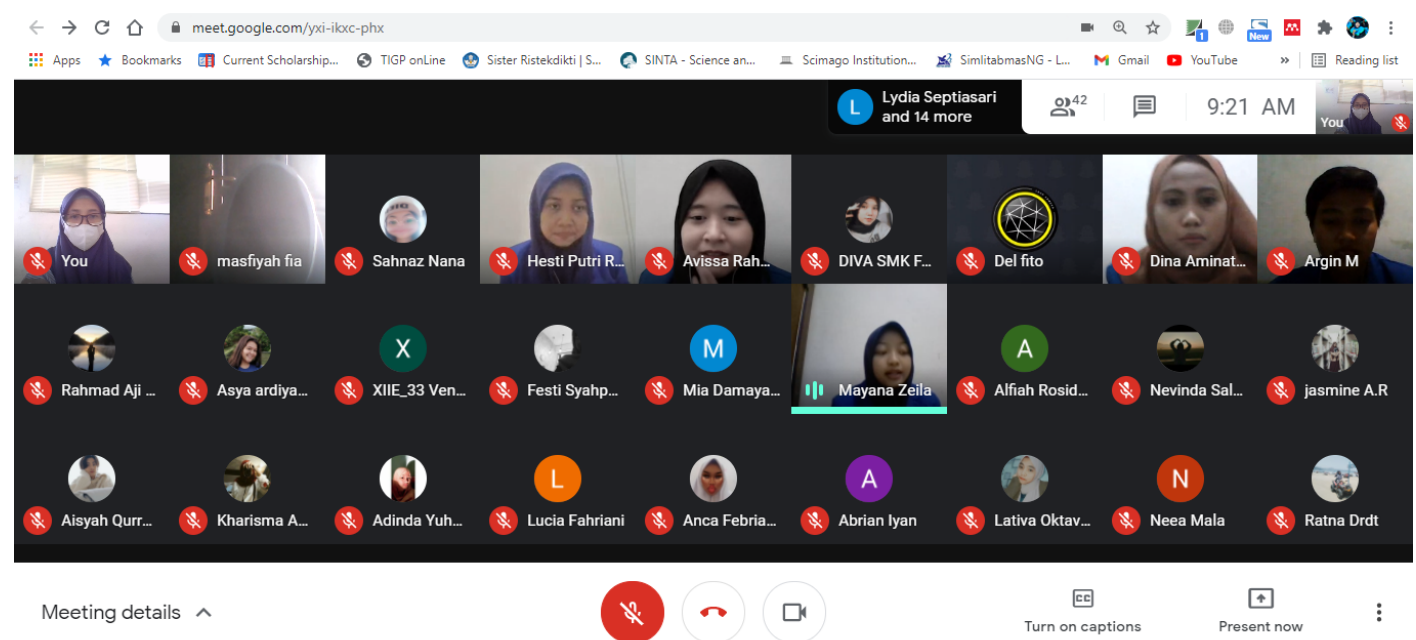

Gambar 1. Dokumentasi Kegiatan

\section{Karakteristik Responden}

Kegiatan ini dilakukan secara terbuka dengan kriteria peserta masyarakat sasaran merupakan siswa SMA/SMK tanpa ada kriteria khusus. Data identitas diri yang telah diisi oleh peserta selanjutnya disajikan pada data berikut.

Tabel 3. Karakteristik Responden

\begin{tabular}{ccc}
\hline Karakteristik & Jumlah & Persentase (\%) \\
\hline $\begin{array}{c}\text { Jenis Kelamin } \\
\text { Perempuan }\end{array}$ & 15 & 88,24 \\
Laki-laki & 2 & 11,76 \\
\hline $\begin{array}{l}\text { Jenis Sekolah } \\
\text { SMA }\end{array}$ & 8 & 47,06
\end{tabular}




\begin{tabular}{lll} 
SMK & 9 & 52,94 \\
\hline Asal Sekolah & & \\
Surabaya & 9 & 52,94 \\
Luar Surabaya & 8 & 47,06 \\
\hline
\end{tabular}

\section{Hasil Diskusi pada Sesi Tanya Jawab}

Pada sesi tanya jawab peserta dipersilakan untuk mengajukan pertanyaan terkait dengan materi yang telah disampaikan. Terdapat beberapa pertanyaan yang diajukan oleh peserta. Pada dasarnya, diskusi yang disajikan pada Tabel 4 tersebut merupakan rangkuman dari pertanyaan-pertanyaan yang diajukan, karena peserta dalam forum melakukan diskusi dua arah, atau dengan kata lain, satu pertanyaan yang diajukan oleh seorang peserta dilanjutkan oleh pertanyaan singkat lain oleh peserta yang lain.

Tabel 4. Resume Hasil Diskusi

\begin{tabular}{cll}
\hline No. & \multicolumn{1}{c}{ Pertanyaan } & \multicolumn{1}{c}{ Jawaban } \\
\hline 1. & Bagaimana jika sudah & Jika sudah terlanjur membeli dan menggunakan \\
terlanjur membeli dan & produk yang belum terdaftar dalam BPOM (setelah \\
menggunakan produk & memastikan secara mandiri pada situs resmi BPOM, \\
kosmetik tanpa ada ijin & https://cekbpom.pom.go.id/) dan telah terbukti bahwa \\
edar dari BPOM? & prosuk tersebut tidak tercantum, hendaknya segera \\
& menghentikan pemakaian pada wajah/tubuh agar \\
& efek pada tubuh tidak semakin parah dan tidak \\
& membeli lagi produk tidak ber-BPOM tersebut. Untuk \\
& selanjutnya sangat dianjurkan sebelum membeli agar \\
& lebih berhati-hati dan tegas dalam memilih produk, \\
& cek latar belakang produk tersebut dan yang paling \\
& penting harus terdaftar dalam BPOM, lebih baik \\
& mengeluarkan dana yang sedikit lebih untuk \\
& memastikan keamanan dan kesehatan tubuh daripada \\
& membeli produk abal-abal tidak ber-BPOM yang \\
& instan namun membahayakan bagi tubuh. \\
\hline &
\end{tabular}


2. Apa yang harus dilakukan jika sudah terlanjur menggunakan produk yang mengandung merkuri ?

Apabila sudah terlanjur menggunakan produk yang mengandung logam berat berbahaya yakni merkuri, segera hentikan penggunaannya, sangat tidak dianjurkan untuk dilanjutkan pemakaiannya karena sudah jelas dilarang penggunaannya pada tubuh menurut peraturan pemerintah, dan dianjurkan untuk mengonsumsi asupan makanan yang dapat meregenerasi sel kulit dengan segera, salah satunya yang kaya akan vitamin D dan E supaya sel kulit mati segera bisa tergantikan oleh sel kulit baru yang lebih sehat tanpa adanya campuran dari logam berat merkuri.

3. Misal apabila membeli produk terkenal $\mathrm{X}$, namun setelah dibuka dan digunakan tekstur dari produk tersebut berbeda kualitasnya dengan produk $X$ yang biasanya (berdasarkan pengalaman penggunaan sebelumnya), apa yang harus dilakukan?
Sebagai konsumen yang baik dan bijak, apabila menemukan kejanggalan pada produk yang telah dibeli, hendaknya memeriksa kebenaran dengan melakukan konfirmasi kepada pihak perusahaan/ industri dengan cara memberikan pengaduan dengan bahasa yang baik dan jelas melalui kontak yang dapat dihubungi yang telah disediakan oleh pihak produksi (biasanya tercantum pada kemasan/brosur produk) berupa email maupun nomor telepon yang dapat dikirim pesan oleh para konsumennya.

\section{Hasil Pengisian Kuesioner}

Berdasarkan gambar yang ditampilkan pada Gambar 2 dan Gambar 3, terdapat pengurangan jumlah peserta yang mengisi kuesioner, dari yang semula 27 menjadi 17 peserta pengisi kuesioner. Sehingga pada laporan ini hanya 17 peserta saja yang dihitung data tingkat 
pengetahuan. Pengukuran pengetahuan pada kegiatan Pengabdian kepada Masyarakat ini dilakukan melalui metode yang dilakukan oleh Arikunto (2010). Dimana, jawaban benar dibandingkan dengan jumlah soal yang diberikan dalam kuesioner. Berdasarkan referensi tersebut, terdapat tiga kategori tingkat pengetahuan, yaitu baik, cukup dan kurang. Pada tabel 5 ditampilkan rentang persentase tiap kategori beserta hasil yang diperoleh dari kegiatan ini.

Tabel 5. Persebaran Tingkat Pengetahuan Peserta

\begin{tabular}{|c|c|c|c|c|}
\hline \multirow{2}{*}{ Rentang Penilaian } & \multicolumn{2}{|c|}{ Sebelum Kegiatan } & \multicolumn{2}{|c|}{ Setelah Kegiatan } \\
\hline & Jumlah peserta & Persentase (\%) & Jumlah peserta & Persentase (\%) \\
\hline Baik (76-100) & - & - & 6 & 35,3 \\
\hline Cukup (60-75) & 11 & 64,7 & 10 & 58,8 \\
\hline Kurang $(\leq 60)$ & 6 & 35,3 & 1 & 5,9 \\
\hline Total & 17 & 100 & 17 & 100 \\
\hline
\end{tabular}

\section{SCORE PRETEST (JAWAB BENAR DARI 15 SOAL)}

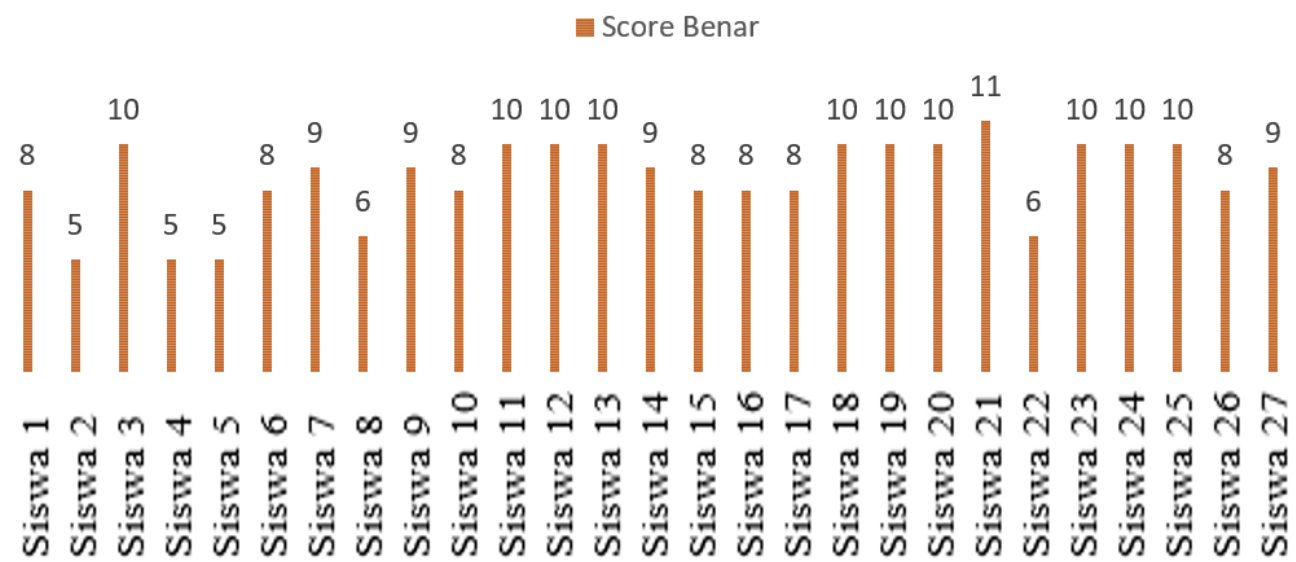

Gambar 2. Hasil penilaian Pre-test peserta 


\section{SCORE POSTTEST (JAWAB BENAR DARI 15 SOAL)}

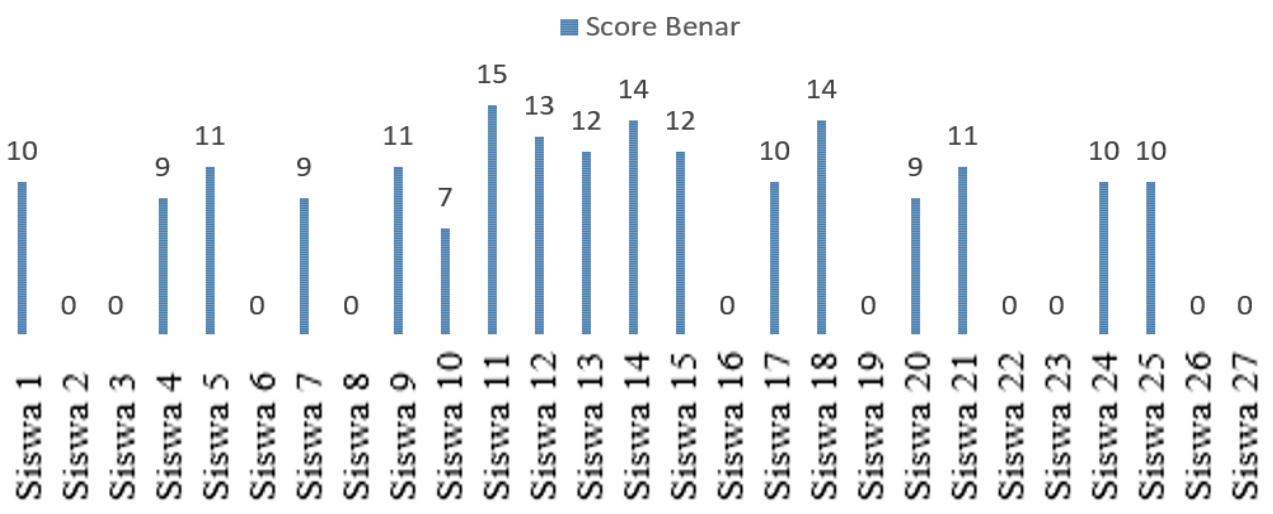

Gambar 3. Hasil penilaian Post-test peserta

Namun, meski demikian sebanyak 11 peserta (64,7\%) mengalami peningkatan pemahaman, dan sisanya sebanyak 4 peserta $(36,4 \%)$ jumlah jawaban benar pada pre-test dan post-test seri atau sama, sementara itu 2 peserta $(11,8 \%)$ mengalami penurunan dalam jumlah jawaban benar antara kuesioner pre-test dan post-test. Data ini membuktikan bahwa lebih dari setengah jumlah peserta pengisi kuesioner mengalami peningkatan pemahaman dalam pemilihan kosmetik yang aman. Pada post-test kegiatan ini terdapat siswa yang tidak mengisi post-test, hal ini disebabkan oleh pengisian post-test dilakukan setelah acara daring ditutup, sehingga kontrol terhadap pengisian post-test dirasa kurang. Evaluasi terhadap pengisian pre-test dan post-test pada kegiatan selanjutnya adalah dengan pemantauan secara langsung, dan menutup kegiatan setelah memastikan semua peserta kegiatan telah mengisi post-test. Selain itu jumlah peserta pada kegiatan ini juga sedikit, hal ini disebabkan oleh terbatasnya waktu atau durasi promosi kegiatan, sehingga penjaringan peserta sangat terbatas. Pada kegiatan selanjutnya promosi kegiatan akan dilakukan dalam waktu yang lebih lama dan gencar, serta dilakukan follow up secara berkala terhadap jumlah peserta, sehingga hasil kegiatan abdimas dapat lebih bersifat representatif. Secara umum kegiatan pengabdian kepada masyarakat ini berjalan dengan tertib dan baik. Meski demikian, edukasi mengenai kosmetik yang aman tetap penting dan perlu untuk terus digalakkan sebagai langkah antisipasi untuk meminimalisir lebih banyak korban kosmetik ilegal. 
JURNAL ASTA

Abdi Masyarakat Kita

Vol. 02 No. 01, Januari 2022

\section{Kesimpulan}

Kegiatan Pengabdian kepada Masyarakat dalam rangka edukasi peningkatan pengetahuan siswa SMA/SMK mengenai kosmetik yang aman telah dilaksanakan dengan baik. Sebanyak 64,7\% mengalami peningkatan pengetahuan setelah diadakannya kegiatan edukasi.

\section{Ucapan Terimakasih}

Penulis mengucapkan terima kasih kepada Akademi Farmasi Surabaya atas dukungan dana yang diberikan melalui skema Pengabdian kepada Masyarakat Internal sehingga kegiatan edukasi ini dapat terlaksana dengan baik.

\section{Daftar Pustaka}

Arifiyana, D. dan Fernanda, M.A.H.F. (2018). Analisis Kualitatif Dan Kuantitatif Cemaran Logam Berat Timbal (Pb) Dan Kadmium (Cd) Padaproduk Kosmetik Pensil Alis Menggunakanspektrofotometer Serapan Atom (SSA). Journal of Research and Technology, Vol. 4 No. 1, 55-62.

https://journal.unusida.ac.id/index.php/jrt/article/view/331/257

Arifiyana, D., Harjanti, Y.S., Ebtavanny, T.G. (2019). Analisis Kuantitatif Hidrokuinon Pada Produk Kosmetik Krim Pemutih Yang Beredar Di Wilayah Surabaya Pusat Dan Surabaya Utara Dengan Metode Spektrofotometri Uv-Vis. Akta Kimindo, Vol. 4(2), 107-117. http://dx.doi.org/10.12962/i25493736.v4i2.5532

Arikunto, Suharsimi. (2010). Prosedur Penelitian. Jakarta: Rineka Cipta.

Badan Pengawas Obat dan Makanan (BPOM) RI. (2014). Peraturan Kepala Badan Pengawas Obat Dan Makanan Republik Indonesia Nomor 17 Tahun 2014 Tentang Persayaratan Cemaran Mikroba Dan Logam Berat Dalam Kosmetika. Jakarta: Badan Pengawas Obat dan Makanan RI. 
Badan Pengawas Obat dan Makanan (BPOM) RI. (2014). Hidrokinon Dalam Kosmetik. Diakses pada 5 Maret 2021, dari http://ik.pom.go.id/v2014/artikel/artikel-Hidrokinon-dalamKosmetik.pdf

Geh, Lampung. (2021). Polisi Gerebek Gudang Kosmetik Ilegal Di Bandar Lampung. Diakses pada 15 Desember 2021, dari https://kumparan.com/lampunggeh/polisi-gerebekgudang-kosmetik-ilegal-di-bandar-lampung-1vvy9ridhLe/full

Kautsar, Nurul Diva. (2021). Pabrik Kosmetik Ilegal Di Padalarang Terbongkar, Ternyata Produksi Pakai Pewarna Ini. Diakses pada 15 Desember 2021, dari https://www.merdeka.com/jabar/pabrik-kosmetik-ilegal-di-padalarang-terbongkarternyata-produksi-pakai-pewarna-ini.html

Maulana, Hafitz. (2018). Penggerebekan Pabrik Kosmetik Palsu. Diakses pada 3 Maret 2021, dari https://tirto.id/penggerebekan-pabrik-kosmetik-palsu-cKsU

Mappiare, Andi. (1982). Psikologi Orang Dewasa. Surabaya: Usaha Nasional.

Mappiwali, Hermawan. (2021). Produksi 850 Paket Kosmetik llegal Di Rumah, 3 Warga Makassar Ditangkap. Diakses pada 15 Desember 2021, dari https://news.detik.com/berita/d-5329312/produksi-850-paket-kosmetik-ilegal-dirumah-3-warga-makassar-ditangkap

Pratiwi, Dinda Surya. (2011). Hubungan Konsep Diri Remaja Putri Dengan Perilaku Membeli Produk Kosmetik Pemutih Wajah. Skripsi. Universitas Negeri Semarang.

Rassat, Fianda Sjofjan. (2021). Polda Metro Jaya Gerebek Pabrik Kosmetik Ilegal Di Jatiasih. Diakses pada 3 Maret 2021, dari https://www.antaranews.com/berita/1973985/poldametro-jaya-gerebek-pabrik-kosmetik-ilegal-di-jatiasih

Wirachmi, Ajeng. (2021). sempat raup untung ratusan juta, penjual kosmetik ilegal ini kini gigit jari. diakses pada 15 desember 2021, dari https://www.idxchannel.com/economics/sempat-raup-untung-ratusan-juta-penjualkosmetik-ilegal-ini-kini-gigit-jari 